\title{
ASPECTS OF REPRODUCTION IN THE ALPACA
}

\author{
M. SAN-MARTIN, M. COPAIRA, J. ZUNIGA, R. RODREGUEZ, \\ G. BUSTINZA AND L. ACOSTA
}

Faculty of Veterinary Medicine, San Marco University, Lima, Peru

(Received 14th August 1967)

\begin{abstract}
Summary. The alpaca, Lama pacos, does not have regular oestrous cycles, but oestrus lasts for 21 to 36 days during the breeding season. Ovulation is induced by coitus. Follicular ovulation rupture occurs spontaneously $26 \mathrm{hr}$ after coital stimulation and can be induced by a single injection of HCG. The low fertility observed in this species is considered to be due to low sperm production in the males and a high incidence of pseudopregnancy in the females. The gestation period has been determined to be about 342 to 345 days.
\end{abstract}

\section{INTRODUCTION}

The alpaca, Lama pacos, is an ungulate belonging to the family Camelidae. Ungulates, generally, are polyoestrous and ovulation occurs spontaneously. The camel, a species closely related to the alpaca, appears to follow the usual ungulate pattern (cf. Asdell, 1964). Nevertheless, preliminary observations showed that ovulation in the alpaca is not spontaneous but is induced by coital stimulation. The investigations recorded here were undertaken in order to extend these observations.

The alpaca is a species that normally lives at high altitudes. The studies were made at an altitude of $4300 \mathrm{~m}$ above sea level at the 'Granja Modelo de Auquenidos de La Raya' in the agricultural department of Cuzco, which is operated by the Ministry of Agriculture of Peru. This work was begun during the breeding season of $1957-58$ and was continued in the following 2 years.

\section{Animals}

\section{MATERIALS AND METHODS}

The animals used belonged to the semi-domesticated herds of the experimental farm. A total of ninety-eight adult female alpacas, ranging in age from 4 to 10 years was used for determination of ovulation by mating or by injection. Most of the animals had been pregnant at least once. Of the ninety-eight animals, eighty were killed in the course of the study.

For the determination of the duration of pregnancy, 306 females were used and the times of mating and parturition were accurately recorded. In this study both varieties of alpaca, suri and huacaya, were used and the data from each were treated separately. All male animals used in the study belonged to a stock kept for breeding purposes on the farm. 


\section{Methods}

The occurrence of oestrus was determined by observation of the characteristic posture of the female. When approached by a male, the female takes a prone position elevating her pelvis and permits copulation to take place. The occurrence of ovulation was determined at autopsy by direct inspection of the ovaries and by recovery of ova from the Fallopian tubes. At various times after mating or injection of human chorionic gonadotrophin (HCG), the genital organs were removed. The Fallopian tubes were flushed with physiological saline by means of a syringe connected to a blunt needle which was inserted through the infundibulum. The washings were collected in a watch glass and examined under a dissecting microscope. For the artificial induction of ovulation, a single intravenous injection of HCG (Prolan B. Bayer) at various dose levels was given.

Semen was collected by means of a sponge placed inside the vagina of an oestrous female. Following copulation the sponge was recovered and its contents were squeezed into a test tube. Animals were killed by cutting the jugular veins and carotid arteries.

\section{RESULTS AND DISCUSSION}

\section{Breeding season and oestrus}

The breeding season of alpacas was found to begin at the end of November and lasted until the end of April or the beginning of May. The females came into heat 24 to $48 \mathrm{hr}$ after parturition. In the absence of the male, the females remained in heat for a long period. At oestrus both virgin and parous females adopted a characteristic prone position with elevation of pelvis. Their behaviour was followed for a 40-day period and it was found that they remained in heat for up to 36 days, with occasional non-acceptance periods of no longer than 48 $\mathrm{hr}$. This may indicate some lowering of intensity of oestrus during a long period.

Oestrus, however, was not sharply defined. (Perhaps the changes in behaviour are not closely related to the physiological changes.) Frequently other females in heat approached the copulating animals and assumed the same posture near to them. It was not unusual to see females in heat showing male behaviour. Pregnant females approached by males never adopted the copulatory posture. Females were observed to accept the male at least 10 days after copulation; presumably in these animals oestrus persisted after ovulation. The duration of copulation frequently lasted for 25 to $35 \mathrm{~min}$, but occasionally it lasted for $1 \mathrm{hr}$.

\section{Appearance of ovaries in unmated animals}

Twelve parous alpacas and four virgin animals, all isolated from males during the breeding season of the study, were killed at different times in oestrus. Their oestrus lasted for 3 to 8 days before slaughter. The ovaries of these alpacas showed corpora albicantia from the last pregnancy and up to thirty or more follicles per ovary, most of them with a diameter of 2 to $3 \mathrm{~mm}$. Occasionally one or two follicles reached a diameter of $10 \mathrm{~mm}$ or more. None of the follicles appeared close to rupture. 
Ovulation induced by mating

The ovaries were examined for evidence of ovulation in nineteen alpacas which were allowed to copulate and were killed at different times after coitus. The findings are summarized in Table 2 which shows that ovulation had occurred about $26 \mathrm{hr}$ after copulation (Table 1 ).

In the animals killed from 20 to $26 \mathrm{hr}$ after coitus the follicular walls showed an increase in vascularization and at about $26 \mathrm{hr}$ after coitus, minute haemorrhagic points were present in the surface of the follicular wall. At $22 \mathrm{hr}$ after coitus in one ovary a 'macula pellucida' surrounded by a capillary crown was observed. After ovulation, follicles in various states of collapse and containing different amounts of blood were noticed.

\section{TABLE 1}

TIME OF OVULATION AFTER MATING

\begin{tabular}{l|c|c}
\hline \multirow{2}{*}{\begin{tabular}{l|c} 
Hr after \\
mating
\end{tabular}} & \multicolumn{2}{|c}{ No. of females } \\
\cline { 2 - 3 } & Total & Ovulated \\
\hline 20 & 1 & 0 \\
22 & 3 & 0 \\
24 & 3 & 0 \\
26 & 5 & 3 \\
28 & 3 & 3 \\
30 to 36 & 4 & 4 \\
\hline
\end{tabular}

TABLE 2

TIME OF OVULATION AFTER INTRAVENOUS INJECTION OF HCG

(200 i.u.)

\begin{tabular}{c|c|c}
\hline \multirow{2}{*}{$\begin{array}{c}\text { Hr after } \\
\text { injection }\end{array}$} & \multicolumn{2}{|c}{ No. of females } \\
\cline { 2 - 3 } & Total & Ovulated \\
\hline 12 & 1 & 0 \\
18 & 1 & 0 \\
22 & 2 & 0 \\
24 & 2 & 2 \\
26 & 4 & 3 \\
28 & 4 & 4 \\
30 & 2 & 2 \\
\hline
\end{tabular}

Induction of ovulation by $H C G$

Different amounts of HCG were used to determine the dosage needed to induce ovulation. Intravenous injection of $10 \mathrm{i}$.u. was sufficient to induce ovulation in one of two animals. Ovulation had taken place in each of seven animals given from 25 to 1600 i.u. of HCG when killed $40 \mathrm{hr}$ after injection.

Table 2 shows that ovulation induced by injection of HCG occurred from 24 to $26 \mathrm{hr}$ after injection, which is about $2 \mathrm{hr}$ earlier than following mating.

Following mating or following injection of HCG, it was observed that the left ovary ovulated more frequently (thirty-two) than the right one (twenty) in fifty-two animals, but the difference is not significant. 
Usually only one follicle ruptured, but both ovaries had an ovulation point in two mated animals and in three animals injected with HCG. In spite of these observations, the probability of obtaining twins is apparently extremely low in this species. Twins have never been recorded in over 12,000 births extending over 12 years at the Granja Modelo de Auquenidos de La Raya.

\section{Low fertility of alpaca}

Mating practice in alpaca breeding varies. Males and females may remain together throughout the year or they may be brought together only at the time of parturition. Usually six to ten males are allocated to 100 females. Under these conditions it has frequently been observed that some females may be mated several times in one day for several consecutive days, while others may be mated on only one occasion. For the study of the low fertility and high rate of pseudopregnancy found in these animals, we have simulated field mating

TABLE 3

FINDINGS ON ALPAGA OVA RECOVERED FOLLOWING VARIOUS PROGEDURES OF MATING

\begin{tabular}{|c|c|c|c|c|c|c|}
\hline \multirow{2}{*}{$\begin{array}{c}\text { Matings } 1 \\
\text { day }\end{array}$} & \multirow{2}{*}{$\begin{array}{c}\text { Mating } \\
\text { days }\end{array}$} & \multirow{2}{*}{$\begin{array}{c}\text { Total } \\
\text { matings }\end{array}$} & \multirow{2}{*}{$\begin{array}{c}\text { Interval } \\
\text { from first } \\
\text { copulation } \\
\text { to killing } \\
\quad(h r)\end{array}$} & \multicolumn{2}{|c|}{ No. of females with: } & \multirow{2}{*}{$\begin{array}{l}\text { Stage of } \\
\text { the eggs }\end{array}$} \\
\hline & & & & $\begin{array}{c}\text { Unsegmented } \\
\text { eggs }\end{array}$ & $\begin{array}{c}\text { Segmented } \\
\text { eggs }\end{array}$ & \\
\hline $\begin{array}{l}1 \\
2 \\
3 \\
1 \\
2 \\
3 \\
1 \\
2 \\
3\end{array}$ & $\begin{array}{l}1 \\
1 \\
1 \\
2 \\
2 \\
2 \\
3 \\
3 \\
3\end{array}$ & $\begin{array}{l}1 \\
2 \\
3 \\
2 \\
4 \\
6 \\
3 \\
6 \\
9\end{array}$ & $\begin{array}{l}48 \\
48 \\
48 \\
72 \\
72 \\
72 \\
96 \\
96 \\
96\end{array}$ & $\begin{array}{l}2 \\
0 \\
1 \\
1 \\
0 \\
1 \\
0 \\
0 \\
1\end{array}$ & $\begin{array}{l}0 \\
2 \\
1 \\
1 \\
2 \\
1 \\
2 \\
1 \\
1\end{array}$ & $\begin{array}{l}1 \text { cell } \\
2 \text { cells } \\
2 \text { cells } \\
4 \text { cells } \\
4 \text { to } 8 \text { cells } \\
8 \text { cells } \\
8 \text { to } 16 \text { cells } \\
\text { Morula } \\
\text { Morula }\end{array}$ \\
\hline
\end{tabular}

TABLE 4

GESTATION PERIOD IN TWO VARIETIES OF ALPACA

\begin{tabular}{l|c|c|c}
\hline \multirow{2}{*}{ Variety } & $\begin{array}{c}\text { No. of } \\
\text { females }\end{array}$ & \multicolumn{2}{|c}{ Gestation period (days) } \\
\cline { 3 - 4 } & 169 & Range & Mean \pm S.E. \\
\hline Huacaya & 169 to 358 & $341 \cdot 6 \pm 0 \cdot 105$ \\
Suri & 137 & 326 to 361 & $345 \cdot 3 \pm 0 \cdot 401$ \\
\hline
\end{tabular}

conditions in order to determine fertility. Thus one group of eighteen normal females, all of which had previously had at least one pregnancy, were mated at random with one of eight males selected from the breeding stock of the farm. The frequency of copulation per day and the number of days on which copulation was permitted were rigidly controlled; the results are presented in Table 3. All females were killed 2 days after the last mating in order to examine their ova. No ovum was recovered from one female. A total of seventeen eggs was recovered from nine animals; six of these were unsegmented and presumed to 
be unfertilized, whereas eleven were fertilized (Table 3). The low fertility is probably due to low sperm production but presumably pseudopregnancy commonly occurs following unsuccessful mating.

These results indicate two important points. First, unfertilized eggs can be recovered from some females which have been mated several times per day or on different days. Failure of fertilization may be due to the early mating with sterile males, which could have induced pseudopregnancy. Second, fertilization commonly occurs with the first mating; this is evident from a comparison of the stage of development of eggs and the interval between first coitus and their recovery.

\section{Pseudopregnancy}

It was estimated that about one third of the females may become pseudopregnant during a breeding season. The duration of pseudopregnancy has not been accurately determined, but observations in the field suggest that it lasts for a long time because many females do not exhibit another oestrus after the first one during the whole breeding season.

\section{Examination of semen}

In order to ascertain the sperm production of alpaca, semen was collected by the intravaginal sponge method and was examined for the presence of spermatozoa. Specimens from 190 males were examined and those which had no spermatozoa in the first collection were examined again on 3 different days. Among thirty-nine males thus examined, no spermatozoa were found in eight males $(20 \%)$. This percentage of apparently sterile males might well account for the high rate of pseudopregnancy seen.

\section{Gestation}

In the breeding season of 1958-59, the dates of mating and of lambing in the following year of two varieties, suri and huacaya, were accurately recorded; Table 4 presents the gestation period of these alpacas. Cabrera \& Yepes (1940) suggested 11 months for the duration of gestation in alpacas; Cardoso (1954) gave 310 days as the most frequently observed duration of gestation. Our results, however, show that gestation in alpacas lasts an average of more than 11 months. The modal values were, huacaya 343 days; suri 346 days.

\section{ACKNOWLEDGMENTS}

The assistance of Drs M. C. Chang and L. Fernandez-Cano in the preparation of this paper is acknowledged.

\section{REFERENCES}

AsDell, S. A. (1964) Patterns of mammalian reproduction, 2nd edn, p. 556. Cornell University Press, Ithaca, New York.

Cabrera, A. \& Yepes, J. (1940) Historia natural ediar. Mamiferos Sud-Americanos, Buenos Aires.

Cardoso, A. (1954) Auquenidos, p. 135. Editorial Centenario, La Paz, Bolivia. 